\title{
CERCEII ELENISTICI DIN AUR DIN COLECTIA ORGHIDAN
}

Alexandru Arbunescu

Podoabele din aur din Colecţia Orghidan, în special cele elenistice, au mai constituit obiectul unor cercetǎri sumare într-un articol semnat de M. Gramatopol şi R. Theodorescu ${ }^{1}$ precum şi într-o comunicare nepublicată, susţinută de M. Sfârlea la o sesiune de comunicări științifice a Muzeului Naţional de Istorie a României. În ambele cazuri, autorii s-au rezumat la o descriere succintă a pieselor elenistice din colecţia aflată în discuţie.

Provenienţa bijuteriilor nu este cunoscută, majoritatea fiind achiziţionate prin reprezentanţi la vânzările publice din ţară şi străinătate.

Am considerat deci utilă o reluare a studiului podoabelor elenistice din Colecţia Orghidan cu descrierea lor în detaliu, insistând asupra elementelor de tehnică precum şi asupra analogilor stilistice care, chiar dacă nu pot oferi o localizare certă a atelierelor de provenienţă a pieselor cercetate aceasta putând fi însă presupusă în unele cazuri - oferă în schimb premisele pentru o datare relativ corectă.

Obiectul cercetării acestei comanicărl se rezumă la cerceii din epoca elenistică, reprezentaţi în colecţia inginerului Constantin Orghidan prin exemplare dintre cele mai reuşite.

1. Pereche de cercei din aur cu toarta circulară din mai multe sârme din aur înfăşurate, ce se îngustează progresiv la un capăt, iar la celălall se termină cu o protomă de leu modelată "au repoussé" din două jumătăți de foaie din aur sudate longitudinal. Gâtul tronconic sudat de cap este bordat cu fir pseudo - perlat, iar partea centrală este decorată cu filigran în forma literei " $S$ " culcată, cu o buclă mai raare şi una mai mică şi cu granule. Sudura gâtului de toarta cercelutui este mascată de un fel de caliciu format din triunghiuri bordate cu fir perlat şi dispuse în motivul "dinţilor de lup". (Inv. nr. C 4209, C 4210. Diametrul toartelor = 19 şi 20 mm.; G = 3,96 şi 4,25 g; Au 900\%0).

Cerceii cu torţi din mai multe sârme înfasşurate, terminate cu protome de leu sunt foarte frecvenţi în mormintele elenistice de la sfârşitul secolului al IV-lea şi începutul secolului al III-lea a Chr. Analogii s-au descoperit la Kerci, la Sedes în Salonic, la Kazani, Amphipolis, Curium, Syracuza, Todi², Odessos (Varna) şi Mal Tepe’. La Rheneia s-a găsit un exemplar cu o mărgea dín pàtră semipreţioasă fixată între protomă şi toarta propriu-zisă ${ }^{4}$. De asemenea, exemplare similare au fost semnalate la Muzeul de artă din Blooming̣ton, Indiana $a^{5}$ şi într-o colecţie particulară din Elveţia ${ }^{6}$.

\footnotetext{
${ }^{1}$ M. Gramatopol, R. Theodorescu, Vechi podoabe din aur în colecţile Cabinetului Numismatic al Academiei Republicii Socialiste Romånia, în "SCIA" seria Artă Plastică, T. 13, Nr. 1, București, 1966, p. 63-92.

${ }^{2}$ R.A.Higgins, Greek and Roman Jewellery, London, 1961, p. 162, pl. 47 C; F.H. Marshall, Catalogue of the Jewellery Greek, Etruscan and Roman in the Departments of Antiquities British Museum by F.H. Marshall, London, 1911, X0XI/1728, 1729.

${ }^{3}$ M. Gramatopol, R. Theodorescu, op. cit., p. 67.

'R.A. Higgins, op. cit., p. 162.

${ }^{5}$ Workshop on ancient jeweler, technology and methodology, Bloomington, Indiana, 1991, p. 50, Inv. nr. 70.42 .2$.

${ }^{6} \mathrm{H}$. Hoffman, P.F.Davidson, Greek gold jewellery from the Age of Alexander, Mainz/Rhein, 1966, p. 106, fig. 26.
} 
Faptul că la Callatis au fost descoperite analogii aproape perfecte ${ }^{7}$ sugerează posibilitatea ca cerceii din Colecţia Orghidan să provină dintr-un atelier din coloniile greceşti dobrogene.

2. O variantă aproape identică a tipului descris mai sus cu excepţia că protoma de leu prezintă coarne din fir pseudo - perłat este cercelul cu nr. inv. C4207 (D = 19,5 mm.; G = 2,18 g; Au $900 \% 0$ ). Cerceii cu capete de leu cu coarne, de fapt leul - grifon persan sunt mai puţin răspândiţi. Aria lor se restrânge la Cipru şi sudul Rusiei. Analogii au fost descoperite la Curium, în Cipru, Amathus şi Olbia ${ }^{8}$. De asemenea, similitudini au fost semnalate la Museum of Fine Arts, Boston ${ }^{9}$, iar o piesă foarte asemănătoare a fost desscoperită în 1961 în mormântul M 1-b din necropola elenistică de la Callatis $^{10}$. Cercelul poate fi datat pe baza analogiilor la sfârşitul secolului al IV-lea şi începutul secolului al III-lea a.Chr.

3. Cercel din aur cu toarta circulară din mai inulte sârme din aur torsionate, subţiată la un capăt, iar la celălalt cu terminaţie în formă de cap de lup sau câine modelat din două jumătăţi de foaie din aur sudate longitudinal. Un fel de caliciu din triunghiuri bordate cu fir perlat, dispuse în motivul "dinţilor de lup" acoperă locul de sudură dintre protomă şi toarta prorpiu-zisă a cercelului. (Inv. nr. C4208 D = $16 \mathrm{~mm} . ; \mathrm{G}=1,42 \mathrm{~g} ; \mathrm{Au} 900 \% 0$ ).

Acest tip de cercel, cu protomă de lup, se datează pe baza analogiilor la sfârşitul secolului al IV-lea şi începutul secolului al IĩI-lea a.Chr. şi este mai rar întâlnit. Au fost descoperite exemplare similare în Eretria, Pergamon şi Aegida ${ }^{11}$.

4. Pereche de cercei din aur cu toarta circulară, din două sârme din aur, torsionate, alăturate prin sudare, ou un fir pseudo - perlat raplicat longitudinal între sãrme. Toarta se îngustează progresiv către un capăt. De capătul mai gros este sudat un tub din aur canelat. La jumătatea lungimii, tubul este prevăzut cu un disc sferic uşor aplatizat, realizat prin sudarea a două jumătăţi de sferă din foaie din aur. Pe linia sudurii este aplicat un fir din aur pseudo - granulat. (Inv. nr. C4220/1-2; G totală = 5,98 g; Au 900\%0). Trei perechi de cercei similari, însă cu toarta din tub din foaie din aur au fost semnalate la British Museum ${ }^{12}$. Pe baza analogiilor, cerceii pot fi dataţi în secolele III-II a.Chr. ${ }^{13}$

5. Pereche de cercei cu toarta reprezentând cornul abundenţei cu statueta lui Eros nưd montată pe gura cornului. Toarta este realizată din două tuburi din foaie din aur prinse printr-o şarnieră. Unul dintre tuburi se îngustează către capătul terminat cu o granulă din aur, celălalt are extremitatea foarte evazată, decorată cu triunghiuri din granule dispuse cu baza pe un brâu perlat flancat de câte un fir din aur torsionat şi unul simplu. De la brâu pornesc spre gura cornului palmete din fir pseudo - granulat cu câte o granulă mai mare în vârf. Buza colnului este ornată cu un fir din aur simplu şi unul perlat. Gura cornului este decorată cu ciorchini din granule, frunze de viţă, rodii şi rozete din foaie din aur. Pe deschizătura cornului este montată statueta din foaie din aur a lui Eros nud, cu un picior uşor îndoit, ținând în mâna dreaptă o phială, iar în stânga un mic corn al abundenţei striat, în gura căruia sunt aplicate granule din aur sugerând fructe. Aripile erosului sunt executate din filigran sudat pe foaie din aur, iar pieptul este ornamentat cu decor filigranat şi granule dispuse în

\footnotetext{
${ }^{7}$ C. Preda, Cateva morminte dirl epoca elenistica descoperite la Callatis, în "SCIV", T. 17, nr. 1/1966, Bucureştl, p. 140, fig. 32; Th. Sauciuc-Säveanu, Callatis, VIII-e rapport preliminaire. Fouilles et recherches les annees 1937-1940, in "Dacia" IX-X/19411944, Bucureşti, p. 340.

R.A. Higgins, op. cit., p. 162.

${ }^{9}$ H. Hoffman, P.F.Davidson, op. cit., p. 106, fig. 25.

${ }^{10} \mathrm{C}$. Preda, op.cit., p. 139, fig. 3/1.

${ }^{11}$ R.A. Higgins, op.cit., p. 162.

12 F.H. Marshall, op.cit., XUII/221L-2212; 2213-2214; 2215-2216.

${ }^{13}$ M. Gramatopol, R. Theodorescu, op.cit., p. 68, fig. VI/1
} 
motivul "nodului lui Herakles". Capul, ca şi restul statuetei sunt realizate într-un stil realist, iar părul e format din granule minuscule. Pe cap este fixat cârligul de prindere al cercelului de tôrtă. (Inv. nr. C4212, $\mathrm{H}=3,17 \mathrm{~mm}$; $\mathrm{G}=7,35 \mathrm{~g}$. Inv. nr. C4213; $\mathrm{H}=32 \mathrm{~mm}$; $\mathrm{G}=7,30 \mathrm{~g}$. Au 850\%0). Realizarea artistică, tehnica filigranului şi a granulaţiei extrem de fine fac posibilă ipoteza provenienţei cerceilor dintr-un atelier din Magna Graecia. Prin analogie piesele pot fi datate la sfârşitul secolului al IV-lea şi inceputul secolului al III-lea a.Chr. ${ }^{14}$

6. Pereche de cercei cu toarta circulară din mai multe sârme din aur înfasşurate, subţiată progresiv spre un capăt, iar la celălalt terminându-se cu statueta unui Eros nud ţinând într-o mână o phială iar în cealaltă un alabastron. (Inv. nr. C4124/1-2; D = 19,5 mm.; G totală = 8,32 g; Au $900 \% 0$ ).

Cerceii cu terminaţii reprezentându-I pe zeul Eros sunt de asemenea frecvenţi în mormintele elenistice de la sfârşitul secolului al IV-lea şi începutul secolului al III-lea a. Chr., fapt explicat prin predilecţia pentru această divinitate în lumea Mediteraneană ${ }^{15}$.

7. Pandantiv de cercel în formă de porumbel cu aripile strânse. Pe pieptul păsării se încrucişează în chip de hamuri patru trese din filigran ce converg către o casetă mică, rotundă, cu peretele din bandă din aur în motivul "dinţilor de lup", care încastrează un "cabochon" din piatră roşie. Terminaţile cordiforme ale treselor au fost umplute iniţial cu o pastă maron, care, astăzi se păstrează in numai una dintre cele patru inimioare. Aripile, din foaie din aur, sudate de corp, se suprapun peste coada cvadrilobată, la rândul ei sudată şi sunt mărginite de un fir simplu. Penele sunt conturate în filigran. Un anou din sârmă subţire, în forma literei "omega", este prins între aripi şi coadă. Porumbelul este montat pe un soclu cubic, cu colţurile rotunjite, din foaie din aur, mărginit sus și jos de câte o tresă. Tresa superioară esłe dublată de un registru de ove conturate în filigran, într-una dintre ele pastrându-se încă o pastă maron. (Inv. nr. C4131; H =21,1 mm., L =24,2 mm., I = 9,6 mm.; $\mathrm{G}=2,67 \mathrm{~g} ;$ Au $900 \% 0$ ).

Analogii apropiate se întâlnesc la un ac de păr din aur din nordal Greciei, datând din a doua jumătate a secolului al III-lea î.e.n. care se află într-o colecţie particulară din Germania ${ }^{16}$. Un exemplar similar, dar din argint, dedicat Afroditei din Paphos, se găseşte la Fitzwilliam Museum din Cambridge ${ }^{17}$.

Mai des întâlnit este porumbelul folosit ca pandantiv de cercel. Două asemenea exemplare au fost semnalate la Musée du Louvre, Paris ${ }^{\mathbf{1 \theta}}$. Înrudiri se nemarcă şi faţă de pandantivul unui cercel, în formă de porumbel de la Muzeul Benaki ${ }^{19}$, precum şi faţă de o podoabă asemănătoare de la Metropolitan Museum, New York ${ }^{20}$.

O plesă similară se mai află în Colecţia Stathatos ${ }^{21}$, iar două perechi de cercei cu analogii semnificative se găsesc la British Museum, şi datează din secolele IV-III a.Chr. ${ }^{22}$. Analogiile permit datarea piesei în a doua jumătate a secolului al III-lea - sec. I a.Chr. Se poate emite ipoteza că pandantivul provine din nordul Greciei, fără a exclude însă, posibilitatea ca piesa să fi fost executată într-unul dintre atelierele din coloniile greceşti dobrogene.

\footnotetext{
14 Ibidem, p. 69, pl. VIII.

${ }^{15}$ R.A. Higgins, op.cit., p. 155.

${ }^{16}$ H. Hoffman, P.F. Davidson, op.cit., p. 188-191, pl. v, nr. 71 şi fig. 71 a, b, c.

17 Paul Jacobsthai, Greek Pins and the Connexions with Europe and Asia, Oxford, 1956, p. 83, fig. 315.

${ }^{18}$ Eugène Fontenay, Les bijoux anciens et modernes, Paris, 1887, p. 108, 109.

${ }^{19}$ Berta Segall, Museum Benaki. Katalog der Goldschmiede - Arbeiten, Athens, 1938, cat. nr. 55.

${ }^{20} \mathrm{C}$. Alexander, Jewelery. The art of the Goldsmith in Classical Times, The Metropolitan Museum of Art, New York, 1928, fig. 73.

${ }_{21}$ P. Amandry, Collection Hélène Stathatos. III. Objets antiques et bizantins, Strasbourg, 1963, fig. 123.

${ }^{2}$ F.H. Marshall, op.cit., XXXIII, 1919-1920; 1921-1922.
} 


\section{THE GOLDEN HELLENISTIC EAR RINGS FROM THE ORGHIDAN COLLECTION}

\section{Abstract}

The Orghidan Collection from the National History Museum of Romania comprises among other remarcable items some exquisite hellenistic ear rings.

The technique details and the style analogies are enough arguments to date the types of the hellenistic earings from Orghidan Collection between the end of the $4^{\text {th }}$ century and the second half of the $3^{\text {rd }}$ century B.C.

The provenience of the pieces is unfortunately unknown because the most of the objects have been acquired for engineer Constantin Orghidan by brokers at auctions in Romania or abroad.

Still, considering the analogies of the most pieces from the Orghidan Collection with the ear rings discovered in the hellenistic cities from Dobrudja, there was a possibility, if not a certitude, that some of the iterns have been manufactured in local workshops. 